\title{
Review of "agricultural involution: the processes of ecological change in Indonesia" by Clifford Geertz
}

\section{Colin McCullough}

Received: 4 September 2018 / Accepted: 11 March 2019 / Published online: 29 March 2019 (C) The Author(s). 2019 Open Access This article is distributed under the terms of the Creative Commons Attribution 4.0 International License (http://creativecommons.org/licenses/by/4.0/), which permits unrestricted use, distribution, and reproduction in any medium, provided you give appropriate credit to the original author(s) and the source, provide a link to the Creative Commons license, and indicate if changes were made.

Book details Geertz, C. Agricultural involution: the process of ecological change in Indonesia. Berkeley, CA: Published for the Association of Asian Studies by University of California Press; 1963. 170 pages, ISBN-13: 978-0520004597.

\section{Introduction}

Agricultural Involution: The Processes of Ecological Change in Indonesia is considered a brilliant application of the principles of cultural ecology placed within the context of Indonesia from the onset of Dutch colonialism in 1619 to after its independence in 1945. Geertz was one of the most accomplished and respected symbolic anthropologists of the twentieth century, however, above and beyond that discipline, Geertz also utilized ecology, geography, economics, sociology and history to further his thesis concerning the phenomena of agricultural involution. Geertz's main goal was to compose a detailed account of the processes responsible for the phenomenon. As Paul Robbins might put it in political ecology terms, “... an intellectual investigation of the human-environment interaction... a political exercise for greater social and ecological justice" (Robbins, 2005, p. xix). This phenomena, as it relates to Indonesia (and particularly Java) was the result of colonialism, rapid population growth and cultural lag produced by social instability and ineffectual public institutions. These factors created an increase in agricultural productivity per hectare, though without the accompanying economic increase per capita, which generated a desperate cycle of poverty and static opportunity, i.e. involution.

C. McCullough $(\bowtie)$

Western State Colorado University, 600 N Adams St, Gunnison, CO 81231, USA

e-mail: colinmccullough@western.edu 


\section{Involution as a CASE study}

The term "involution" was coined by anthropologist Alexander Goldenweiser, and describes a culture that cannot (or does not) adapt and or expand its economy, but continues to develop only in the direction of internal complexity and inefficiency (Hui, 2009). Though technically a book, Agricultural Involution is fundamentally a case study in the form of a monograph. The sociopolitical problems that were a result of Dutch colonialism remain in the form of a corporate neo-colonial system that has resulted in the most rapid ecological degradation in the world (Aldilla, Achmad \& Josi, 2013). For the purposes of this review, a summary of Geertz's study and his conclusions will be critiqued and his findings placed within a framework of political ecology and associated theory.

A logical place to begin when reviewing this monograph is to provide an explanation of the traditional agricultural, or more precisely horticultural, practices that the indigenous Indonesian peoples practiced before Dutch colonialism morphed those production techniques and introduced plantation monoculture. These two techniques are swidden and sawah horticulture, both of which rely on a balance that is maintained through knowledge of the regional ecology, down to individual ecosystem dynamics. The first of these two, swidden, is an extensive form of slash, burn and fallow polyculture, which when done properly is highly sustainable and conducive to the tropical ecology of Indonesian forests. The secondary forest growth created by this technique promotes the health of the soils, while simultaneously protecting the old growth stands. The second is sawah, which specifically refers to wet rice production, again a technique that is highly productive in the rain-soaked, thin-humus terraces built on the relatively steep terrain within the region's valleys. The importance of these traditional practices is that they preserved a balance between population rates and carrying capacities of the ecological system.

With the arrival of the Dutch, a concerted effort to increase agricultural production for export (alongside simple extraction), whether by introduction of plantation monoculture or modification of the sawah system from rice to sugar cane with technological advancements in irrigation, began in earnest. The introduction of the "Culture System," in essence an imperialist system of forced acculturation and exploitation, instituted corvee (taxation) labor and land-tenure systems that benefited only the Dutch State and the plantation owners (Geertz, 1963, p. 82). The increased yields of the sawah that were not modified to sugar production, which has an inherent capacity to produce year round if cultivated as such, led to a dramatic population increase. However, under colonial rule there was no manufacturing investment or industrial economic expansion and subsistence farming necessarily intensified, leading to ever-increasing poverty (Geertz, 1963). The Dutch effectively created a dual economy: one for the flow of capital (in the form of raw materials) to the Netherlands produced through corvee labor and one that was (in essence) a subsistence economy for the Indonesians (Boer \& Boonstra, 2014). 


\section{The lingering effects of colonialism}

With independence after WWII, industrial growth, a growth of capital through GDP, and improved public institutions were expected to empower Indonesian society due to the demise of colonialism. However, this did not occur. Why? Geertz provides an answer that lies within the industry that historically holds great power over Indonesian culture... agriculture. As opposed to endogenous manufacturing and development of infrastructure and export trade networks, industrial agriculture (especially plantation production of sugar and palm, a huge part of the economy) was composed of a traditional (oppressed) labor force and a managerial elite (Geertz, 1963). Regarding this structure, Geertz relates, "The Javanese did not become impoverished because they were 'static'; they became 'static' because they were impoverished" (Geertz, 1963, p.142). While this could be interpreted as a purely Marxist iteration, it is nonetheless the case. The power was sequestered to the elites in the plantation system, and by proxy this institution held all the political sway over how hydrology, land and cultivation were managed. In essence, contracting out to foreign corporate interests simply replaced the colonial system.

Even with the expropriation of the remaining colonial plantation operations, without nonagricultural production (industry) or manufacturing, those increasing populations spilled into urban areas resulting in "urbanization without industrialization [...in which...] the share-the-poverty pattern is simply extended to embrace both urban and rural dwellers" (Geertz, 1963, p.146). Some argue that private mineral, oil and gas interests have invigorated the nation's economy, and to some degree this is true, although this has overwhelmingly produced the same ramifications as Geertz's agricultural explanation (Hayes, 1964). These industries, and industrial agriculture (e.g. palm oil production), are structured in a corporate neo-colonialist paradigm, which simply reinforces inequitable social strata and further evolves into a Malthusian-Darwinian dynamic at the expense of the Indonesian people and its ecology. A stark explanation by Geertz about the enduring effects of colonialism over the Indonesian people is that "the real tragedy of colonial history in Java after 1830 is not that the peasantry suffered... [but that] it suffered for nothing" (Geertz, 1963, p. 143). By this he is referring to the continuing domination of multinational corporations over the poverty stricken general population through the exploitation of the nation's resources. It is a model that elevates the status of a few elite individuals, concentrating power, and leaving the majority of the population without social institutions to insure their security (Hui, 2009). Without effective public institutions and serious regulation, continued resource exploitation does little to help the average Indonesian while the ecology suffers.

\section{Enduring relevance}

Although Geertz composed Agricultural Involution some fifty years ago, it remains relevant to this day. It is a rather technical read, as it is riddled with data and theory, and Geertz's style of prose takes some getting used to, but it is a comprehensive inquiry into the relationship between culture and nature. It could be 
described as an early exploration into what we would now refer to as Immanuel Wallerstein's world systems theory with an emphasis on agriculture and ecology. Moreover, Geertz delves deeply into the social catalysts that have led to current state of Indonesian political ecology, a testament to his development of thick description. While Indonesia has improved its institutions and industry, and a rising urban middle class has developed, this has largely occurred through the mechanism of multinational corporatism and industrial agriculture, which perpetuates poverty in the rural areas and is devastating the ecology. Geertz warns against presupposition in contrasting his study of Indonesia as a generalization to similar scenarios, as it is a detailed and specific account, though he does investigate the differences between Indonesia and Japan in the nineteenth century. However, it is difficult not to draw parallels to current political ecology issues across the globe. How the land is used, and at what social and environmental costs, is material to the whole of humanity and the ramifications are at a tipping point. In that sense, Agricultural Involution was ahead of its time.

Acknowledgements Not applicable.

\section{Funding}

Not applicable.

\section{Availability of data and materials}

Data sharing not applicable to this article as no datasets were generated or analyzed during the current study.

\section{Availability of supporting data}

Not applicable.

\section{Authors' contributions}

$\mathrm{CM}$ is responsible for all research and composition with regard to this article.

\section{Ethics approval and consent to participate}

Not applicable. 


\section{Consent for publication}

Not applicable.

\section{Competing interests}

The author(s) declare they have no competing interest(s).

\section{Publisher's Note}

Springer Nature remains neutral with regard to jurisdictional claims in published maps and institutional affiliations.

\section{References}

Aldilla Stephanie, S., S. Mas Achmad, and K. Josi. 2013. The progress on governing REDD+ in Indonesia. OpenAIRE. EBSCOhost Accessed 19 Mar 2018.

Boer, F., and W. Boonstra. 2014. The historical dynamics of social-ecological traps. Ambio (3): 260. https:// doi.org/10.1007/s13280-013-0419-1.

Geertz, C. 1963. Agricultural involution: The process of ecological change in Indonesia. Berkeley, CA: Published for the Association of Asian Studies by University of California Press.

Hayes, S. 1964. Agricultural involution: The processes of ecological change in Indonesia Clifford Geertz, 190. The Annals Of The American Academy Of Political And Social Science, pg.

Hui, Y. 2009. The (un)changing world of peasants: Two perspectives. SOJOURN: Journal Of Social Issues In Southeast Asia 24 (1): 18-31.

Robbins, P. 2005. Political ecology: A critical introduction. Malden: Blackwell Pub. 